Published by the University of KwaZulu-Natal

https://journals.ukzn.ac.za/index.php/JICBE

(C) Creative Commons With Attribution (CC-BY)

Journal of Inclusive cities and Built environment. Vol. 2 Issue 1

How to cite: S. Bekker. 2022. African cities in the 2020s: Weaknesses and Strengths. Conference Proceedings for International Symposium on Inclusive-Cities: Achieving Inclusive Cities Through A Multidisciplinary Approach, 2021 28-30 June. Journal of Inclusive cities and Built environment. Vol. 2 Issue 1, Pg 45-49.

\title{
AFRICAN CITIES IN THE 2020S: WEAKNESSES AND STRENGTHS
}

\author{
By S. Bekker
}

Published 31 January 2022

\begin{abstract}
A series of case studies will illustrate trends in migration and urbanization in urban Africa. Weaknesses in the search for inclusivity - especially during and after COVID - refer particularly to the continuing dominant roles of urban (as well as national and global) elites in these cities and the associated high levels of urban poverty and inequality. Strengths refer particularly to the roles of the better qualified urban youth, to the spread of digital skills and means of communication, and to the presence of both global as well as national positive influences in these cities.
\end{abstract}

KEY WORDS Urban Africa, poverty, inequality.

Simon Bekker: Stellenbosch University. 


\section{INTRODUCTION}

Let me start with a short impression of a Summer School conference I attended at Point Sud in Bamako in 2017. Its title was New Forms of Political Participation in Africa and the researchers were young African scholars speaking to their recent doctoral studies. Most projects were urban-based and focused on movements involving young activists who organized by utilizing digital social media platforms. These movements targeted national rather than urban-level political objectives.

I left the conference with three enduring impressions. First, that digital media had significantly invaded urban political movements; secondly, that little direct research addressed climate change though service delivery was researched; and thirdly, though many did not succeed in their short-term political aims, this form of political participation and protest was here to stay.

After the conference moreover, I was left wondering whether the conclusion Therborn and I had reached in 2012 after a survey of capital cities in Africa remained true, a conclusion underlining the absence of inclusivity in these cities (Bekker and Therborn 2012:202):

"(African capital) cities were powerless in the face of problems posed by an avalanche of fleeing immigrants and of informally employed residents.... It was now that Africa became the continent of slums. But the crisis and its effects were nevertheless managed by the state - the central state-not the city. African capitals and other big cities did not collapse into general misery. They polarised, between the large, impoverished majority and a ... political clique around the president and around business protégés of the president ..."

So, let me turn to the issue of migration and of urbanization.

Africa is today the least urbanized continent. At the same time, during the 20 years after 1995, the urban population of sub-Saharan Africa doubled and will exceed that of Europe over the next decade.
The process of urbanization, as we know, involves the mass transfer of populations from rural to urban settings. This happens in two ways - either through the migration of people from rural to urban areas, or through the incorporation of rural areas into expanded urban areas or, of course, of both.

My first case study on migration toward a city aims to illustrate, simply, that this movement of people includes crossborder migration (not only internal migration) and that the collective identities of new urban migrants - their shared meanings - shift and change once they reside in their new urban place.

In a study some years ago of Francophone migrants in Cape Town, South Africa, Lekogo's research (2002) revealed that migrants from Francophone countries - The Congos, Gabon, Senegal, Cameroon, Ivory Coast - found that their Francophone background - their French-speaking background - which was much less important to them at home than national and ethnic backgrounds, emerged as a significant shared identity in Cape Town. As a small minority, sharing this linguistic identity created, for many, a new important bond.

The second case study of Yaoundé, the capital city of Cameroon, illustrates the rapidity of urbanization and urban growth over the first 50 post-independence years. As a capital city moreover, the use by the national government and the presidency of national as well as global architecture (monuments, public places, street names) was designed to attract internal migrants from around the country to the city. Significantly, Togolo (2019) argues that members drawn from each of the two presidents' ethnic groups were not privileged as internal migrants during their tenures. Rather, presidential exercise of power in the capital city led to the co-optation of elites throughout the country, enabling migratory networks to be continually forming around these elites. This appears to have been the case under both Ahidjo and Biya.
On a flight back to South Africa from Yaoundé in Cameroon, I asked my fellow-passenger seated next to me, a Cameroonian businessman practicing in South Africa, why the two homes of Professors I had visited in Yaoundé were incomplete. Each had a ground floor and a first floor and a large number of metal rods sticking out of the unfinished second floor. He answered by explaining that the land on which much of inner Yaoundé was built is owned by the 'autochtones', the original residents of the area. The land accordingly was treated as customary leasehold and the owner of the house leased the plot on which it is built from the "traditional autochtones". In much of urban South Africa - excluding the informal settlements - land is freehold tenure, he said, and owning a plot gives the homeowner access to a bank bond where the plot is used as collateral. The bond, essentially a lease from the bank, is used to complete home construction. Owners in Yaoundé are not able to obtain equivalent bonds from banks and continue construction solely when they have cash.

This anecdote raises the issue of land tenure in African cities, to which I will now turn.

The province of Kinshasa and its multiple municipal councils are responsible for the delivery of local government services to its residents. The quality and scope of these services - for the majority of this urban population - varies from poor in the former colonial city centre (of former Leopoldville) - l'ancienne cité - to poorer in the planned zone - cités planifiées and subsequently virtually non-existent in the more recently incorporated peripheral zone. Accordingly, urban dwellers living in the capital city receive most urban services informally rather than from their municipalities. 
Figure 1: The three zones defined by urban planning and land tenure Kinshasa 2011

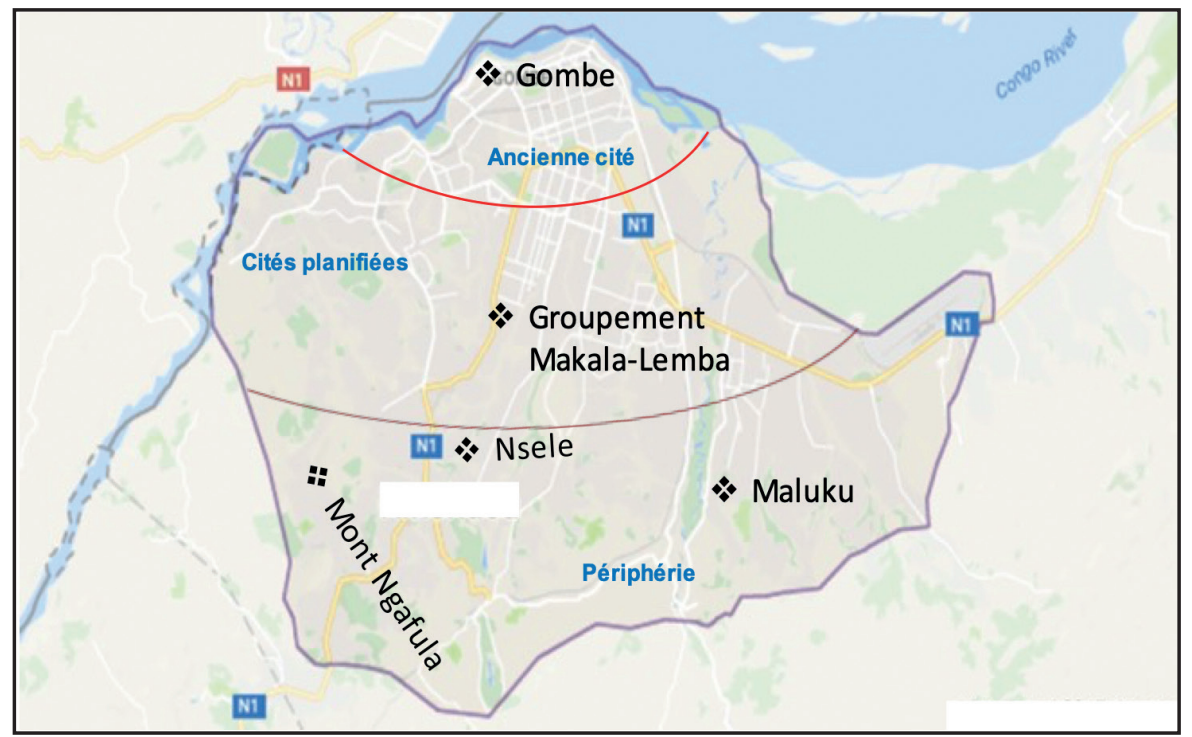

Source: Ibaka 2019: 75

It is consequently no surprise that many residents consider the traditional institutions of chieftaincies - within the boundaries of Kinshasa - as genuine and worthy of support. These traditional institutions are continually adapting to this new urban environment. The process of adaptation, argues lbaka (2019), has not been uniform: its form depends not only on the nature of chiefly authority but also whether institutions find themselves in the former colonial zone, in the new planned zone or in the peripheral zone of Kinshasa. In the former colonial zone, traditional institutions have disappeared and have been replaced by modern urban state institutions, the bourgmestres and their municipal councils; in the planned zone, they have lost much of their authority; and in the periphery, they tend to coexist with their modern equivalents. With the creation of a national institution called the National Alliance of Traditional Authorities of Congo (ANATC), some of the traditional leaders in the city have been offered a statutory opportunity to collaborate and to cohabit with modern state institutions.

Let us turn to Harare and its urban periphery. Today, Domboshava is both a dormitory village for Harare, the capital city of Zimbabwe, as well as a peri-urban communal area hosting traditional settlements deemed rural in policy terms.

In the context of rapid urbanization in Zimbabwe and less than adequate policies on rural development and on land tenure, land transactions in Domboshava shifted from customary inheritance in the tribal line to individualized land transactions such as direct land sales and renting. This privileged financially better off households. Household survival strategies also shifted from farm-based to off-farm and non-farm activities.

Significantly, Hungwe (2014) shows that the rapid urbanization in this peri-urban communal area was also due, in large measure, to the Zimbabwean government's two controversial land reform campaigns: the Fast Track Land Reform Programme of 2001 which led to a chronic weakening of the country's agricultural infrastructure and an associated out-migration of farm-workers, in the first place, and to Operation Murambatsvina, also officially known as Operation Restore Order, which was a largescale Zimbabwean government campaign forcibly to clear slum areas across the country. Launched in 2005, its impact on Harare's slum areas led to high migration streams of Harare residents to Domboshava.

In addition, Hungwe argues that the diminishing influence of patriarchy in Domboshava creates opportunities for women to buy land for themselves. This appears to be true for those women able to raise finances for themselves but not for the poor.
If the recent rapid urbanization of Yaoundé which we saw earlier is impressive, the case of Luanda, capital city of Angola is extraordinary. In a phrase, the metropolitan population grew from some one million residents in 1985 to eight and half million today. The authoritarian state has, through a vigorous urban redevelopment and housing policy, succeeded in what Croese (2016) calls developmental patrimonialism. In fact, the personal and centralized rule of the president and presidency was mobilized for developmental purposes since this was in the interests of those in power. As a consequence, with the availability of foreign financing for the petro-state and of foreign business allies, stateled housing development in Luanda has delivered on scale to many in the middleclass and elite. In the case of the Zango housing project, despite the fact that its new residents have no legal tenure, houses have become valuable assets. This is not only illustrated by the prices that are paid for houses on the informal market but also by their use as sources of investments or income generation. One could say that inclusivity has grown, for the middle classes.

\section{CONCLUSION}

A forward-looking discussion and pause from presenting the case studies; my views are presented below. It appears that the pessimistic prognosis Therborn and I made some ten years back is only partially factual. The majority do seem to remain largely trapped in informal housing, with few individual tenure rights, and with few immediate employment opportunities outside of the informal sector. This state of impoverishment. However, it is not the same for all, as we saw in Luanda and in Kinshasa. The privileged minority on the other hand appear to have done better the increasing role of digital and virtual platforms, the skilling and mobilization of young urban residents, the presence of globalizing influences in capital cities, policies aimed at smart cities, all may be viewed as strengths African cities will employ in the years ahead. Whilst patrimonialism privileges the powerful, it may also promote certain types of urban development. 
So what is there to be done about this key weakness of African cities?

I finish with a suggestion being made in South Africa for residents of South African cities. It is basically an experiment to address the key weakness identified. I quote from a CDE text (2021: 17)

"South Africa is a country with millions of unskilled, inexperienced workers looking for work in a labour market that drives firms to minimise low-skilled employment and emphasise skill- and capital-intensive activities.

Few people in government or organised labour seem to believe that there is much prospect of expanding low-wage employment. Of those who think it is possible, most think that doing so would have to compromise the living standards of existing workers. So create an island on which to test whether more jobs could be created in low-wage, low-skilled sectors, and would do so in a way that did not diminish the rights or incomes of any existing employee of any existing firm. The island could be a SEZ (Special Economic Zone) located close to a city (e,g, Port Elizabeth or Gqeberha). Such a development project 'on an island' would show (or fail to show) that such labour-intensive production (initially simply for export) with relaxed labour employment constraints and a minimum wage could become an example from which the country and its cities could scale up its employment without major disruptions to the 'modernizing' sections of the national economy."

Examples of goods could be textiles and mass-produced industrial goods.

Whether the South African Special Economic Zone (SEZ) tryout will work depends on a number of things:

- Will the national government allow it?

- Will trade-unions allow it?

- Will large business interests allow it?

- Will its success as an SEZ be followed by transfer to South African cities as a whole?
Whatever the outcome, the key weakness of African cities - their deepening polarization and inequality - remains and requires intervention, as has been widely documented and stated during the COVID pandemic that has exacerbated this divide.

So my conclusion is that the emerging strengths many have identified of African cities in the future - the increasing role of digital and virtual platforms, the skilling and mobilization of young urban residents, the presence of globalizing influences in capital cities, policies aimed at creating smart and green cities - all will privilege the better-off, rather than the urban population as a whole. Unless the key weakness - polarization and inequality - is addressed at the same time. 


\section{REFERENCES:}

Bekker S \& G Therborn (eds) 2012 Capital cities in Africa: power and powerlessness. Cape Town and Dakar: CODESRIA and HSRC Presses.

CDE (2021) 'What if South Africa had a special economic zone that was actually special?' Centre for Development and Enterprise. https://www.cde.org.za/ (April 21st, 2021)

Croese Sylvia 2016 State-led housing delivery as an instrument of developmental patrimonialism: the case of post-war Angola. African Affairs, 1-21 doi: 10.1093/afraf/adw070

Hungwe Emaculate (2014) Land transactions and rural development in the Dombashava peri-urban communal area, Zimbabwe. Doctoral dissertation, Stellenbosch University

Ibaka P (2019) Adaptation des institutions traditionnelles a la gestion foncière de Kinshasa, ville-capitale (1960-2016). Doctoral dissertation, Stellenbosch University

Ibaka P (2021) 'Traditional chiefs and traditional authority in Kinshasa, capital city of the Democratic Republic of the Congo (DRC)', Ch 5 in Bekker S., S. Croese \& E. Pieterse (eds) 2021 Refractions of the National, the Popular and the Global in African Cities. Cape Town: African Minds.

Lekogo, Rodolf Estime (2002) The Dynamics of Francophone African Migration to Cape Town after 1994.

Doctoral thesis, Stellenbosch University.

Togolo JP (2019) Yaoundé après l'indépendance : Les changements migratoires dans le processus d'urbanisation d'une ville-capitale 19602010. Doctoral thesis, Stellenbosch University'

Togolo JP (2021) 'National projects in the postcolonial capital city: the example of Yaoundé in Cameroon.' Ch 2 in Bekker S., S. Croese \& E. Pieterse (eds) 2021 Refractions of the National, the Popular and the Global in African Cities. Cape Town: African Minds. 
Notes 